
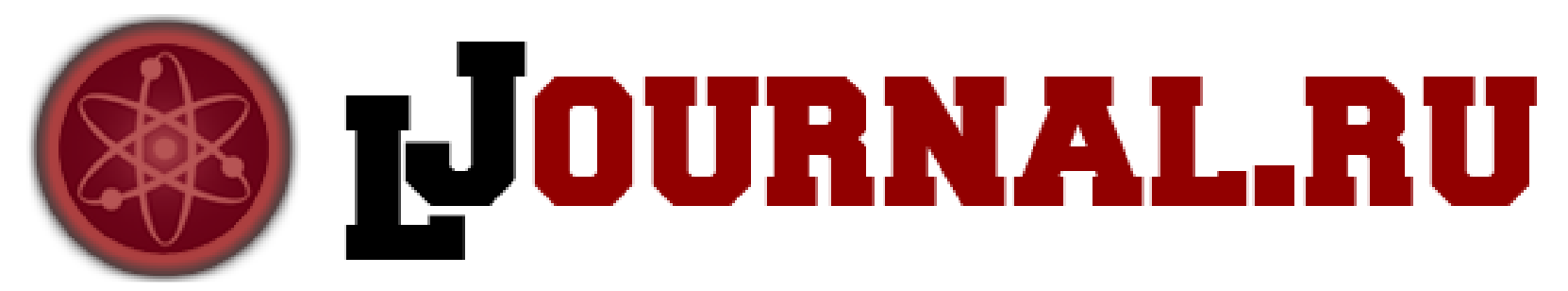

Доброногова Е.А. МАОУ - школа №9 Жуковский, Россия

doi: 10.18411/1j2016-2-06

\title{
Трудности перевода при обучении иностранному языку
}

В современном обществе мотивация к изучению иностранного языка как инструмента межкультурного общения заметно возросла. В ходе обучения иностранному языку учителю необходимо привить обучающимся навыки грамотного перевода. Перевод играет огромную роль в культурном развитии человечества, так как благодаря переводу люди знакомятся с жизнью, бытом, историей, литературой и научными достижениями других стран. Именно поэтому обучающимся важно знать быт, традиции и нравы народа, язык которого они изучают, то есть все то, что составляет его самобытный, национальный облик. Незнание реалий ведет к ошибкам в переводе или обесцвечивает перевод, лишая его национального колорита, оно может также привести к грубым ошибкам, которые могут изменить смысл оригинала.

Таким образом, для правильного перевода необходимо глубокое знание всех аспектов языка: фонетики, грамматики, лексикологии и стилистики, без чего не могут быть практически разрешены трудности грамматического, лексического и стилистического порядка.

В данной статье мы рассмотрим некоторые синтаксические и лексикограмматические проблемы, возникающие у обучающихся при переводе с английского языка на русский. 


\section{1) Синтаксические проблемы перевода.}

Различия в порядке слов в английском и русском языках часто требуют перестройки предложения при переводе. В огромном большинстве случаев несоответствие грамматического строя русского и английского языков проявляется именно в порядке слов в предложении. Дело в том, что в английском предложении наблюдается строгий порядок слов: подлежащее, сказуемое, дополнения, обстоятельства.

В русском языке, по сравнению с английским, порядок слов более свободный. Поэтому при переводе часто приходится перестраивать английское предложение в соответствии с синтаксическими нормами русского языка. Например:

A scientific conference was recently held in our university. (Недавно в нашем университете провели научную конференцию.)

При переводе на русский язык английское предложение подверглось полной перестройке: обстоятельства времени и места стоят в начале предложения, употреблено неопределенно-личное сказуемое.

Еще один пример:

My brother has a new job. He doesn't like it. (У моего брата новая работа. Она ему не нравится.) В данном случае дополнение и подлежащее при переводе поменялись местами.

Ярким примером несовпадения порядка слов при переводе с английского языка на русский являются случаи с оборотом there is / there are, так как предложения с этим оборотом требуют перестройки. Например:

There is a book and a newspaper on the table. (На столе лежат книга и газета.) Конструкции с данным оборотом лучше переводить с конца предложения, сам же оборот there is/ there are не переводится.

2) Лексико - грамматические проблемы перевода.

а) грамматические проблемы перевода.

В употреблении личных и притяжательных местоимений в английском и 
русском языках наблюдается расхождение. Вследствие этого необходимо разобрать некоторые наиболее характерные случаи. В английском языке отсутствует местоимение «свой», что вызывает затруднения у обучающихся. Вместо этого местоимения употребляются притяжательные, согласующиеся с подлежащим:

$\mathrm{He}$ is going out with his friend. (Он собирается идти гулять со своим другом). В данном предложении в качестве местоимения «свой» выступает притяжательное местоимение his - «его». Кроме того, в английском языке есть категория притяжательных местоимений в независимой форме, то есть употребляющихся без существительного, эта категория отсутствует в русском языке. Например, словосочетание «мой друг» можно передать двумя способами: 1) my friend; 2) a friend of mine.

Трудности возникают у учащихся и в употреблении местоимения 3-го лица единственного числа it, которое переводится «он», «она», «оно» и означает неодушевленные предметы, а также животных, в то время как местоимение he (он) означает мужчину, а местоимение «she» (она) - женщину.

Обучающимся следует объяснять, что употребление единственного и множественного числа существительных в английском и русском языках часто не совпадает. Абстрактные существительные, обычно выражающие отвлеченные и общие понятия, в английском языке могут употребляться в конкретном смысле и становятся тогда именами существительными исчисляемыми. Как исчисляемые существительные они могут употребляться во множественном числе. В русском же языке такие существительные всегда являются неисчисляемыми и не употребляются в форме множественного числа. Например:

Our lives would be very difficult without electricity. Наша жизнь была бы очень трудна без электричества. В русском языке слово «жизнь» в его широком значении (как в данном случае) не употребляется во множественном числе. 
б) лексические проблемы перевода.

Правильный выбор слова для полной передачи значения слова в переводимом тексте является одной из основных и наиболее сложных задач перевода. Трудность этой задачи обусловливается полисемией английского языка.

Слово как лексическая единица в английском и русском языках не всегда совпадает. Часто одному слову в русском языке в английском соответствует составное слово или целое словосочетание (например, «карусель» - merry-goround; «обедать» - to have dinner и наоборот: to stare - «пристально смотреть», glance - «быстрый взгляд»).

Важно научить обучающихся выбирать правильное значение слова, исходя из контекста. Однако в ряде случаев наблюдается совпадение основных значений слова в английском и русском языках и несовпадение производных. Например, основное значение слов table и «стол» совпадает. Но в русском языке слово «стол» имеет еще значение «питание», «полный пансион», тогда как в английском языке такое значение развилось от слова board. С другой стороны, другое значение слова table - «таблица» отсутствует в русском языке.

Особое внимание при обучении английскому языку необходимо уделять интернациональным словам, которые могут иметь совершенно иное значение, чем в других языках. Ученику, переводящему с английского языка, естественно, приходит на ум аналогичное слово, которое, однако, в русском языке имеет иное значение. Например: английское слово complexion - «цвет лица» ошибочно переводят русским словом «комплекция» - «телосложение». Английское слово conductor имеет значение «дирижер», тогда как русское слово «кондуктор» имеет много значений, одно из которых «проводник поезда, вагона, наблюдающий за порядком и проверяющий билеты у пассажиров; проводник трамвайного вагона, продающий трамвайные билеты». Интернациональные слова часто становятся тем, что называют «ложными друзьями» переводчика. Яркие примеры: a magazine (журнал, но не магазин), to realize (понимать, но не 
реализовывать).

Передача так называемой «безэквивалентной лексики», обозначающей национальные реалии, представляет собой проблему, требующую особого внимания. Чаще всего такие слова переводятся развернутым словосочетанием, описывающим данное понятие: snapdragon - рождественская игра, в которой хватают ртом изюминки с блюда с горящим спиртом.

В других случаях передача таких слов происходит при помощи заимствования иностранных слов, например, parliament - парламент, speaker спикер, alderman - олдермен (член городского управления), sheriff — шериф и Т. П.

Таким образом, учителя иностранного языка должны научить школьников переводить английские предложения и тексты, сохраняя своеобразие оригинала, но не нарушая при этом, однако, норм русского языка. 